\title{
EDUKASI VISUAL SEBAGAI MEDIA PEMBANTU PEMBELAJARAN JARAK JAUH PADA SISWA SEKOLAH DASAR
}

\author{
Andreana Lingga ${ }^{1}$, Ardi Makki Gunawan ${ }^{2}$, Nugroho Widya Prio Utomo ${ }^{3}$ \\ ${ }^{1}$ Pradita University \\ ${ }^{2}$ Pradita University \\ ${ }^{3}$ Pradita University
}

andreana.lingga@pradita.ac.id, ardi.makki@pradita.ac.id, nugroho.widya@pradita.ac.id

\begin{abstract}
Abstrak
Pembelajaran Jarak Jauh yang berlangsung selama pandemi covid 19 tidak berjalan efektif di semua tingkat pendidikan dan semua daerah, sekalipun di Jabodetabek yang tergolong daerah Urban. Termasuk di SDN Jurang Mangu Timur 02 Tangerang Selatan, di mana tidak semua guru dapat mengoperasikan medium pembelajaran daring karena tidak memiliki fasilitas seperti laptop, wifi, serta kemampuan untuk menyusun materi secara daring.

Dosen dan mahasiswa DKV Pradita bekerjasama dengan guru SDN Jurang Mangu Timur 02 membuat edukasi visual untuk membantu menjelaskan materi yang diajarkan agar pembelajaran lebih efektif dan menarik. Dengan berdasarkan metode kualitatif, kegiatan ini akan menghasilkan materi edukasi berupa motion graphic. Dengan menggabungkan unsur audio, visual, dan tekstual, diharapkan menjadi sebuah pengalaman baru bagi guru dan siswa serta menjadi stimulus agar kegiatan belajar mengajar menjadi lebih aktif, efektif, dan menarik meskipun dilakukan secara jarak jauh.
\end{abstract}

Kata Kunci: edukasi visual, visualisasi, materi ajar, pembelajaran jarak jauh.

\section{PENDAHULUAN}

Pandemi covid-19 membuat seluruh kegiatan belajar mengajar harus dilakukan secara jarak jauh, tak terkecuali bagi siswa di bangku sekolah dasar SDN Jurang Mangu Timur 02, Tangerang Selatan. Setelah ditelusuri kegiatan belajar mengajar secara jarak jauh di SD tersebut tidak berjalan dengan baik, faktor-faktor penghambatnya antara lain: 1) Siswa/i SDN Jurang Mangu Timur 02 mayoritas berasal dari kalangan menengah ke bawah, sehingga tidak memiliki jaringan Wifi di rumah masing-masing siswa sehingga bergantung pada kuota Internet saja. Siswa juga harus berbagi device (handphone) dengan orang tua mereka; 2) Tidak semua guru dapat mengoperasikan platform atau medium pembelajaran daring seperti Zoom dan Google Meet; 3) Tidak semua guru memiliki fasilitas seperti laptop, wifi, serta kemampuan untuk menyusun materi secara daring seperti: presentasi powerpoint dan video editing; 4) Bahan ajar bergantung pada ketersediaan materi di YouTube; 5) Proses pembelajaran jarak jauh sejauh ini dilakukan secara terbatas melalui whatsapp. 


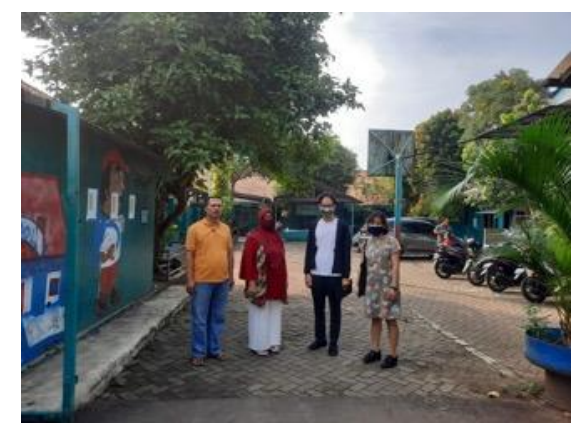

Gambar 1. Penjajakan Kerjasama dengan SDN Jurang Mangu Timur 02. Sumber: Dokumentasi penulis (2020)

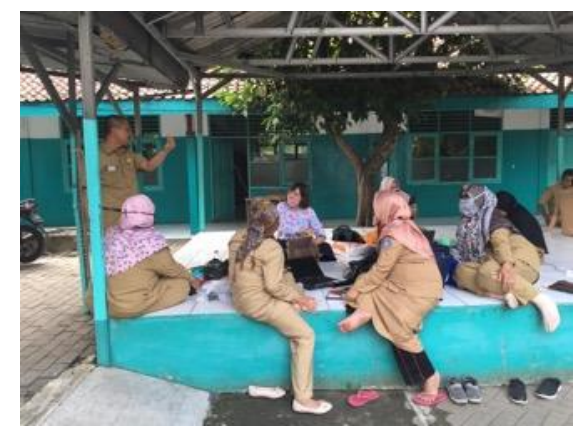

Gambar 2. Wawancara dengan guru SDN Jurang Mangu Timur 02. Sumber: Dokumentasi penulis (2020)

Tantangan dan peluang bagi pengajaran adalah dapat menambah aturan pelibatan (Rules of Engagement) dan berpikir kreatif tentang bagaimana visual dapat mendukung tujuan edukasi.

Dengan adanya kegiatan PKM ini diharapkan dapat membantu kegiatan pembelajaran jarak jauh di SDN Jurang Mangu Timur 02, sehingga murid dan guru mendapatkan pengalaman belajar-mengajar yang lebih baik, menarik, serta interaktif meskipun dilakukan secara jarak jauh.

\section{METODE}

Kegiatan ini merupakan upaya perekaman proses kreatif dalam pembuatan edukasi visual untuk siswa sekolah dasar serta sebagai pemecahan masalah terhadap keadaan di lingkungan sekitar. Metode yang digunakan adalah metode kualitatif, mengumpulkan dan bekerja dengan data nonnumerik dan berupaya menafsirkan makna dari data ini, sehingga membantu kita memahami proses belajar siswa secara jarak jauh melalui studi atau tempat yang ditargetkan. Metode ini lebih bersifat memberikan gambaran secara jelas suatu permasalahan sesuai dengan fakta di lapangan.

Berikut adalah tahapan-tahapan dari penggunaan metode tersebut untuk mendukung kegiatan ini agar terlaksana dengan baik meskipun dilakukan secara daring: 1) Persiapan. Pelaksana melakukan persiapan sebelum kegiatan PKM dilakukan antara lain mencari sekolah-sekolah yang mengalami kesulitan selama pembelajaran jarak jauh berlangsung. Setelah pelaksana menentukan SDN Jurang Mangu Timur 02 Tangerang Selatan sebagai subyek kegiatan PKM ini, dilakukan perjanjian kerjasama antara kedua belah pihak sebagai tanda komitmen dalam menyukseskan kegiatan ini. 2) Pengumpulan Data. Dimulai dengan melakukan observasi kebutuhan masyarakat dalam hal ini adalah SDN Jurang Mangu Timur 02, tim pelaksana telah melakukan kunjungan ke SDN Jurang Mangu Timur 02. Observasi awal ini dalam rangka mendapatkan data-data dan profil sekolah. Setelah persetujuan kerjasama antara kedua belah pihak dilakukan, tim pelaksana kemudian melakukan wawancara dengan pihak SDN Jurang Mangu Timur 02 untuk mendapatkan data kualitatif, wawancara tersebut dilakukan dengan kepala sekolah, dan guru-guru dari masing-masing angkatan yang ditunjuk sebagai koordinator kelas. Dari proses wawancara pelaksana mendapatkan data kualitatif, data tersebut dikumpulkan kedalam beberapa point dan didapati bahwa materi ajar akan menjadi objek dalam kegiatan PKM ini. Permasalahan materi ajar dari setiap kelas berbeda-beda, oleh karena itu dibutuhkan koordinasi oleh tim pelaksana dalam pembuatannya. 3) Koordinasi dengan mahasiswa. Setelah permasalahan dirumuskan dan menentukan objektif untuk kegiatan ini, tim pelaksana berkoordinasi dengan mahasiswa melakukan pembagian kelompok untuk mengerjakan masingmasing topik materi ajar agar lebih fokus dan terarah. Setiap kelompok membuat grup whatsapp untuk Pendidikan 
mempermudah komunikasi dengan masing-masing guru SD koordinator.

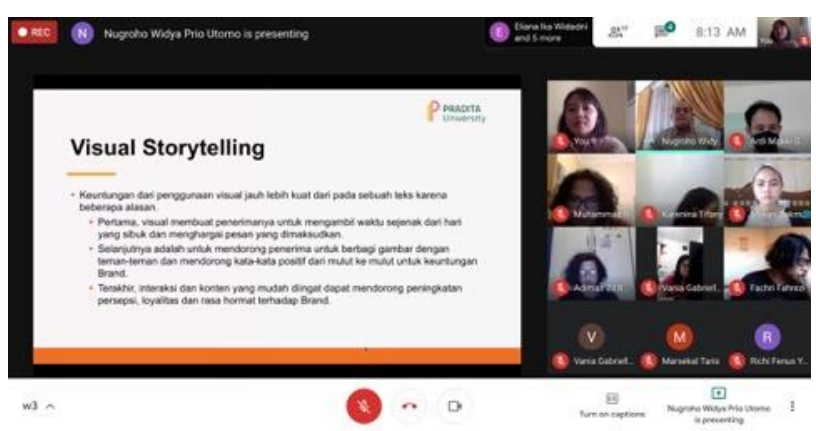

Gambar 3. Koordinasi dan pembelajaran materi oleh penulis dan mahasiswa yang dilakukan secara daring. Sumber: Dokumentasi penulis (2020)

4) Proses Pengerjaan. Tim pelaksana membuat materi ajar berupa edukasi visual dengan media animasi atau motion graphic dari setiap angkatan kelas, yang menarik secara visual dan memberikan penggambaran faktual bagi siswa sekolah dasar, serta dapat didistribusikan secara daring untuk mendukung kegiatan pembelajaran jarak jauh. Tim pelaksana juga secara rutin melakukan komunikasi progres pembuatan materi ajar agar hasil yang diperoleh baik dan efektif. Tim pelaksana mempelajari buku dan literatur yang berkaitan dengan materi edukasi visual, selain itu pelaksana bersama dengan mahasiswa belajar serta mengkonsultasikan hasil materi ajar dengan praktisi dan profesional dalam bidang animasi atau motion graphic. 5) Pendistribusian. Hasil kegiatan PKM berupa materi ajar dalam bentuk video animasi ini didistribusikan secara daring ke SDN Jurang Mangu timur 02. Materi ajar yang dijadikan topik atau tema akan diberikan pada murid-murid SDN Jurang Mangu Timur 02 pada semester genap 2020/2021 sedangkan video-video animasi sudah diserahkan pada akhir semester ganjil 2020/2021 ke masingmasing guru koordinator. 6) Umpan balik dari lokasi PKM. Selama proses pembuatan video, setiap kelompok kelas secara aktif melakukan asistensi dengan guru-guru koordinator kelas dalam whatsapp group, seperti yang dilihat di Gambar 4. Sehingga luaran video animasi merupakan hasil kolaborasi antara pelaksana dan guru, tanggapan senantiasa diberikan dalam setiap tahap pembuatan video animasi. Proses pembuatan yang melibatkan kedua belah pihak membuat luaran kegiatan PKM ini dianggap ideal dan baik bagi tim pelaksana maupun guru SDN Jurang Mangu Timur 02 karena topik telah disesuaikan oleh kebutuhan masing-masing kelas.
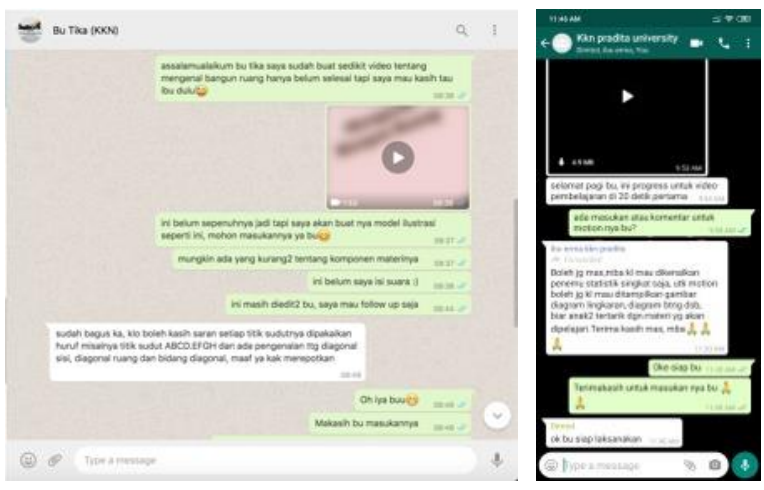

Gambar 4. Tanggapan Guru Koordinator selama proses pembuatan video animasi.

Sumber: Dokumentasi penulis (2020)

Secara keseluruhan kegiatan ini bertujuan untuk memberikan pelatihan serta pemahaman tentang edukasi visual yang berguna untuk membantu pembelajaran jarak jauh bagi kedua belah pihak. Dengan hasil objektif tersebut diharapkan dapat memberikan ide serta gagasan siswa sekolah dasar untuk bisa memahami materi pelajaran dengan lebih baik. Selain itu kegiatan PKM ini bermanfaat juga untuk meningkatan kemampuan dan kreativitas baik pelaksana, mahasiswa, guru, maupun siswa sekolah dasar melalui medium yang digunakan.

\section{HASIL DAN PEMBAHASAN}

Pada dasarnya hasil dari kegiatan ini merupakan hasil dari proses menerjemahkan tema materi ajar siswa sekolah dasar ke dalam bentuk visual yang lebih mudah didistribusikan dan dipahami secara daring. Objek edukasi visual berupa animasi atau motion graphic merupakan hasil dari 
penggabungan teks, gambar/ilustrasi, foto, diagram, serta suara yang ditransformasi ke topik materi ajar.

Dua hal penting yang hilang saat proses pembelajaran jarak jauh dilakukan yaitu pengalaman murid terhadap: 1) Komunikasi nonverbal, melibatkan penggunaan ekspresi wajah dan bahasa tubuh untuk membantu mengkomunikasikan sikap, karakter dan kepercayaan. 2) Pemanasan. ini merupakan strategi yang memberikan peluang untuk mengembangkan kepercayaan dan lingkungan yang aman, di mana para murid dapat bereksplorasi dan berimprovisasi (Koppett, Adu F.O, 2014).

Kemampuan seorang guru di SD jurang mangu Timur 02 sangat mengandalkan interaksi sosial dan pengalaman antara dirinya dan muridmuridnya. Dengan pembelajaran yang konvensional dan tradisional di sini seorang guru dapat berimprovisasi dengan materi pengajarannya. Improvisasi adalah hal yang sangat penting dalam proses mengajar dan belajar karena improvisasi dapat menjadi alat, instrumen, bahan, perangkat baru atau modifikasi yang sudah ada untuk melayani fungsi tertentu (John, Adu F.O, 2014). Agar guru dapat berimprovisasi, guru harus inovatif, banyak akal dan kreatif, baik dalam berpikir dan memanipulasi ketangkasan (John, Adu F.O, 2014).

Bagi tim pelaksana, aspek murid untuk mengalami dan merasakan improvisasi menjadi hilang saat pembelajaran jarak jauh dilakukan. Oleh karena itu hal yang berkenaan dengan "improvisasi" sedapat mungkin tetap terjadi dengan mensimulasikannya melalui medium-medium visual seperti motion graphics dan whiteboard animation.

Video animasi salah satu bentuk edukasi visual yang mendasar dijadikan sebagai hasil dari kegiatan ini juga sebagai solusi untuk menjawab permasalahan yang dialami guru-guru SDN Jurang timur 02 dalam melakukan kegiatan belajar mengajar secara jarak jauh. Fokus pelaksana dalam program ini adalah memperlihatkan pemetaan visual akan informasi-informasi yang ada di materi ajar guru. Materi ini diharapkan membantu guru dalam memberikan pengajaran secara jarak jauh, serta memudahkan siswa sekolah dasar dalam mencerna konsep-konsep yang abstrak dan kompleks. File video animasi dikerjakan dan dibuat sederhana dan menarik dengan format resolusi 720p (1280 x 720) sehingga mudah didistribusikan melalui media sosial whatsapp. di mana platform whatsapp menjadi medium utama guru-guru SDN Jurang Mangu Timur 02 dalam melakukan pembelajaran daring. File video ini nantinya dapat dipergunakan kembali di dalam kelas saat kegiatan belajar (tatap muka) sudah kembali normal dengan cara diputar dalam proyektor di ruang kelas. Selain itu hasil grafis dari video ini nantinya bisa ditransformasi ke dalam bentuk poster cetak, yang juga bisa dipajang di sisi-sisi kelas sehingga siswa dapat lebih mudah mengingat materi tersebut.

Video animasi dapat secara dinamis merepresentasikan sebuah konsep (dan miskonsepsi) tanpa memiliki fokus terhadap aksi naratif. Video animasi dapat menempatkan pengamat dalam peran sebagai animator/narator pada saat gambar sedang dikonstruksikan, yang kemungkinan dengan tujuan untuk membantu penonton membentuk mental dari konsep yang diberikan. Animator membangun ekspektasi penonton dengan gambar tahap demi tahap dan diakhiri titik akhir dengan gambar yang komplit; titik baru kemudian dimulai dengan papan kosong dan gambar baru. Fungsi animasi terlihat seperti garis gambar yang menghibur yang dapat dianggap sebagai desain emosional dalam instruksi multimedia (Mayer, 2014).

Visual Storytelling. Didefinisikan sebagai penggunaan gambar, video, infografis, presentasi, dan visual lainnya di platform media sosial untuk menyusun cerita grafis seputar nilai dan penawaran sebuah brand (dalam hal ini materi pelajaran atau edukasi). Gambar tidak hanya melukis seribu kata. Mereka dapat mengkomunikasikan beberapa hal yang jauh lebih spesifik daripada kata-kata seperti emosi tertentu, perasaan tertentu, suasana hati tertentu, hal-hal yang hampir tidak mungkin untuk

$$
\text { Pendidikan }
$$


disampaikan menggunakan kata-kata. Gambar bertindak seperti cara pintas ke otak: kita adalah makhluk visual, dan kita diprogram untuk bereaksi terhadap visual lebih dari kata-kata. (Walter, \& Gioglio, 2014). Dengan mengikuti definisi tersebut, peran mahasiswa Pradita dalam menciptakan visual edukasi di sini adalah memberikan nilai, bentuk estetik, dan juga dimensi narasi pada konten materi ajar dengan menimbulkan respons secara emosional dari gambar melalui teknologi video, dan strategi visual seperti: infografis, atau animasi untuk mendukung pengajaran yang berbasis tradisional, seperti halnya yang dilakukan di SDN Jurang Mangu, menjadi lebih dinamis.

Aspek pembelajaran visual adalah sesuatu yang harus dipertimbangkan oleh semua guru ketika mereka merencanakan, mempraktikkan, dan merefleksikan situasi belajar mengajar. Selanjutnya, aspek pembelajaran visual menjadi bagian dari setiap desain sumber daya e-learning misalnya: videopodcast, platform sosial dan perangkat seluler (Buhl, 2011). Siswa harus memperhitungkan kompleksitas aspek-aspek ini dalam desain pembelajaran, dan harus mempertimbangkan aspek visual dalam didaktik yang ditentukan dalam aplikasi pembelajaran serta integrasinya dalam praktik komunikasi khusus. Hal ini tidak hanya membutuhkan kompetensi perencanaan, praktik dan refleksi dalam proses belajar mengajar.

Berikut ini adalah proses serta potongan gambar hasil video animasi kolaborasi antara tim pelaksana dengan guru-guru SDN Jurang Mangu Timur 02:

\section{- Matematika Bangun Ruang}

Proses dimulai dengan membuat desain karakter terlebih dahulu dapat dilihat pada Gambar 4. Karakter fiktif yang sederhana sengaja dibuat untuk mengundang penonton. Karakter wajah dan manusia di sini diilustrasikan ke dalam bentuk yang lebih sederhana. Karakter manusia pada gaya ilustrasi seperti komik mempunyai peran penting dan kuat karena di dalamnya adanya sifat simbolis yang kuat sehingga pembaca bisa mengidentifikasikan karakter fiktif itu sebagai dirinya. (Mccloud, 1993).

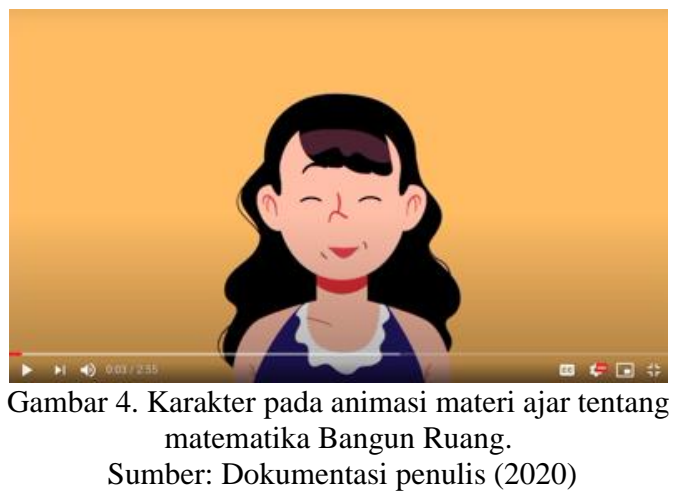

Pada bagian ini, pelaksana menempatkan pengamat dalam peran sebagai animator atau narator pada saat gambar sedang dikonstruksikan. Hal ini memungkinkan penonton membentuk citra mental dari konsep yang diberikan. Ide berfokus terhadap perpindahan peran yang bisa dimainkan oleh pelaku pedagogis, yaitu: murid, guru dan materi ajar. Murid bisa berperan dan berimajinasi untuk menempatkan dirinya sebagai guru, dan juga guru bisa menempatkan posisinya sebagai murid. jadi batasan antara guru dan murid berada dalam kondisi yang flexible, sebuah materi ajar dapat menjadi wadah di mana pengetahuan dapat dialami oleh guru maupun murid.

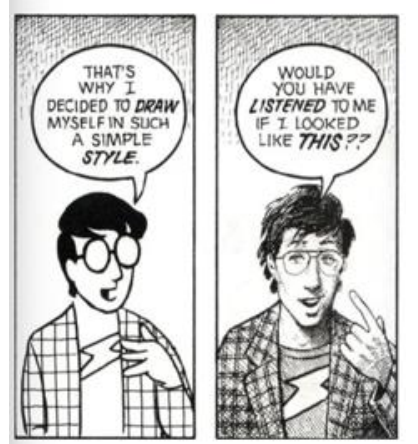

Gambar 5. Penggambaran ilustrasi ke bentuk yang lebih sederhana/komik.

(Scott, 1993)

Guru dalam merancang materi ajar dapat menimbang posisinya sebagai murid terlebih dahulu. Sebagai kesimpulan, ilustrasi mempunyai peran penting dan makna baru di dalam konteks 
visual edukasi untuk memfasilitasikan pertukaran peran antar pelaku pendidikan.

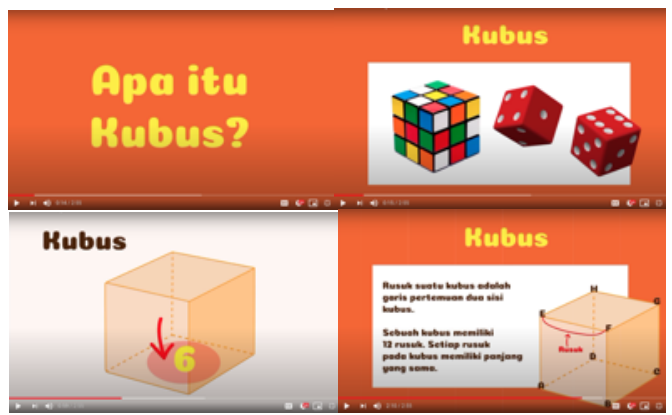

Gambar 6. Potongan gambar pada animasi materi ajar tentang matematika Bangun Ruang. Sumber: Dokumentasi penulis (2020)

\section{- Pengetahuan Alam tentang Tata Surya}

Pada bagian tata surya pelaksana juga mengawali materi dengan menampilkan karakter fiktif yang mengenalkan planet-planet yang berada di sekitar bumi, lalu gerak orbit bumi bulan dan matahari yang kemudian diakhiri dengan revolusi. Planet-planet tersebut digambarkan dengan gaya visual vektor dilengkapi juga dengan warna-warna yang menarik. Murid diajak untuk belajar seperti membaca komik, jadi penyampaian materinya seperti komik yang didongengkan. Narasi mengenai tata surya divisualisasikan menjadi utama di sini. karena meskipun dilakukan secara tatap muka materi tentang tata surya ini sulit dipahami oleh siswa karena guru tidak bisa memvisualisasikan materinya. Dengan adanya interaksi dengan gaya seperti ini, gaya visual tidak hanya menjadi sesuatu yang sifatnya indah tapi dia bisa jadi bagian penting dalam transformasi sosial dan kultural.

Proses pembuatan video animasi dimulai dengan pembuatan storyboard yang dapat dilihat pada Gambar 7. Storyboard merupakan papan cerita yang terdiri dari gambar-gambar yang berurutan, fungsinya seperti naskah cerita namun digambarkan secara visual.

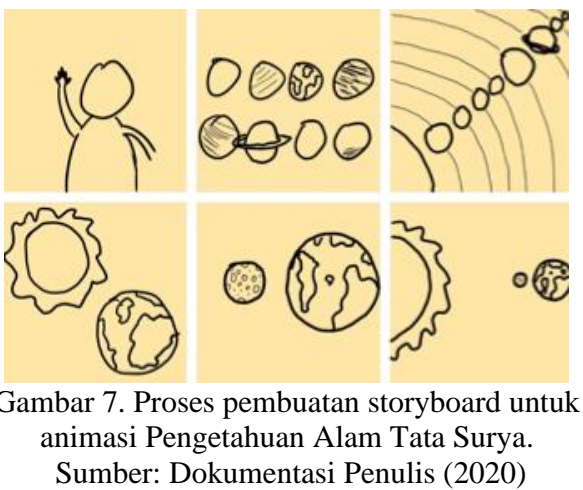

Pembuatan storyboard sekaligus untuk memastikan tidak ada cerita yang terlewat saat gambar sudah masuk dalam proses editing video. Dengan adanya storyboard tim pelaksana bisa memiliki bayangan yang sama akan alur cerita video animasi yang dibuat. Setelah storyboard, proses pembuatan dilanjutkan ke tahap pencarian referensi gambar, yang dijadikan acuan atau moodboard dalam pembuatan ilustrasi. Tim pelaksana menentukan gaya ilustrasi vektor dianggap sesuai untuk pembuatan animasi cerita tentang tata surya untuk siswa sekolah dasar. Setelah storyboard dan gaya ilustrasi telah disepakati, proses pembuatan animasi akan lebih mudah dilakukan, terutama jika dikerjakan dalam tim.

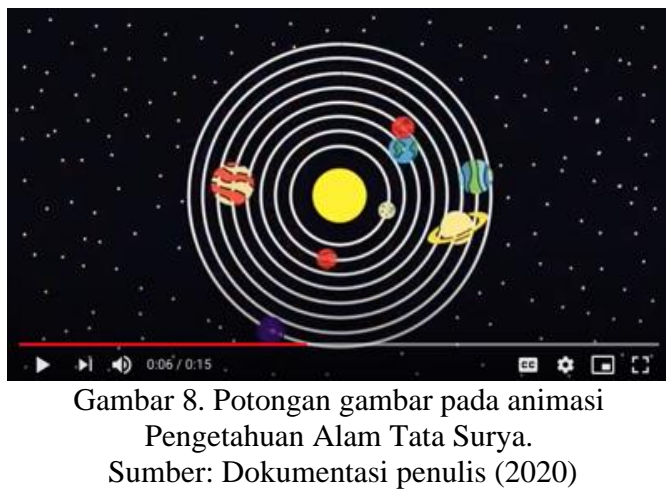

\section{- Pengetahuan Alam tentang proses} Metamorfosis

Gambar visual baik secara ilustrasi maupun foto sangat berpengaruh pada pembuatan video animasi ini. Gambar visual membawa bagaimana materi ajar itu dinarasikan. Membawa penonton

$$
\text { Pendidikan }
$$


fokus terhadap dimensi narasi dari sebuah konten yang diajarkan tentang bagaimana suatu konten disampaikan secara berurutan oleh ilustrasi karya mahasiswa Pradita. Terlihat pada Gambar 9 storyboard materi yang hendak menceritakan tentang proses metamorfosis hewan, diterapkan proses yang sama dalam membuat sebuah komik, yakni penggambaran secara berurutan. Peran narasi di sini digunakan untuk menggantikan proses perubahan bentuk. Itulah alasan mengapa dipilih gaya ilustrasi, tidak menampilkan foto, atau gambar nyata.

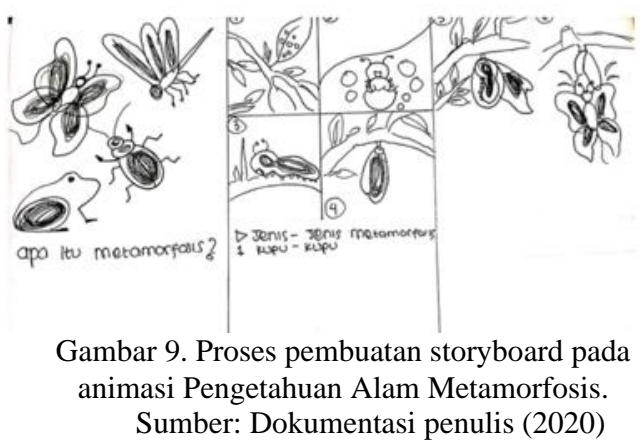

Dalam hal ini pelaksana juga berperan dalam memperbaiki gambar-gambar ilustrasi yang ada di buku tematik kurikulum nasional 2013 yang sebelumnya dirasa kurang dapat memvisualisasikan topik-topik di dalamnya. Karena buku hakikatnya penuh dengan teks, dan visualnya justru berperan sebagai sekunder, padahal untuk tema-tema tertentu visual sangat dapat menunjang pembelajaran, membuat murid lebih memahami, dengan memiliki penggambaran yang sama akan topik tertentu.

Pada ilustrasi di Gambar 10, karakter hewan digambarkan melalui ekspresi, gestur dan emosi dengan warna dan bentuk serangga.

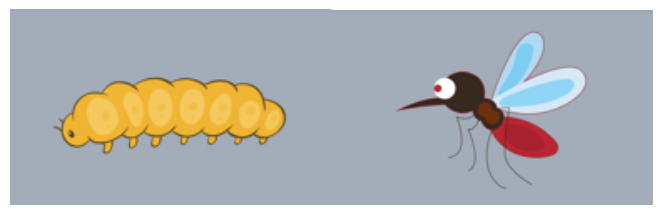

Gambar 10. Karakter hewan pada animasi Pengetahuan Alam Metamorfosis. Sumber: Dokumentasi penulis (2020)
Walaupun narasi metamorfosis kerap direpresentasikan sebagai sesuatu yang positif dan sesuatu yang indah bahkan lucu, perlu juga untuk mengkomunikasikan perasaan yang lainnya seperti: seram, atau menakutkan. perasaan yang lain dari proses-proses metamorfosis serangga yang sebenarnya sebuah proses yang aneh dan terkesan tidak wajar.

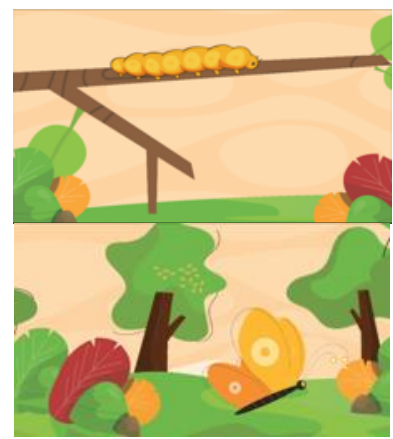

Gambar 11. Potongan gambar pada animasi Pengetahuan Alam Metamorfosis. Sumber: Dokumentasi penulis (2020)

Diharapkan kedepannya penggambaran ilustrasi untuk topik seperti ini perlu diperbaiki untuk menuai perasaan atau emosi yang sesuai, gunanya agar murid juga bisa mengenal perasaan-perasaan seram, dan tidak hanya berpihak pada yang baik atau gembira tetapi juga perasaan perasaan yang di luar dari dugaan manusia itu sendiri.

Dampak bagi mitra sasaran, dengan adanya edukasi secara visual berupa video animasi ke siswasiswi sekolah dasar dapat meningkatkan pemahaman siswa akan suatu materi yang tidak bisa hanya dijelaskan dalam teks maupun ilustrasi editorial (buku). Misalnya pada materi tentang pemahaman pengetahuan alam Tata Surya, dengan adanya video animasi siswa memiliki gambaran konkrit tentang orbit planet-planet di tata surya. Siswa dapat memiliki penggambaran yang sama dengan apa yang dijelaskan guru dikelas. Tidak hanya tata surya, tapi topik-topik lain seperti bangun ruang, metamorfosis, bahkan ilustrasi pada pelajaran PKN menjadi lebih konkret dengan adanya edukasi visual.

Jika pembelajaran jarak jauh masih dilakukan kedepannya, medium video animasi dapat membantu proses interaksi, improvisasi dan apresiasi dari guru yang hilang saat pembelajaran tatap muka berubah menjadi daring. Siswa tetap dapat tetap merasakan

$$
\text { Pendidikan }
$$


kehadiran guru meski tidak secara langsung bertemu, siswa juga mendapatkan pelajaran yang interaktif lewat visual-visual menarik yang ditampilkan pada video.

Karena bentuk materi ajar ini video animasi, maka materi akan sangat mudah didistribusikan lewat media apa saja, termasuk lewat whatsapp, dimana whatsapp group merupakan media utama dalam pembelajaran jarak jauh yang dilakukan SDN Jurang Mangu Timur 02. File berupa video memungkinkan siswa untuk membukanya kapan saja, sehingga tidak menjadi masalah jika siswa tersebut berbagi perangkat smartphone dengan orang tua mereka. Materi dapat dibuka kapan saja, menyesuaikan kondisi masing-masing keluarga.

Hasil video animasi akan mulai didistribusikan ke murid SDN Jurang mangu pada semester genap 2020/2021, materi yang dibuat sudah menyesuaikan untuk materi di semester tersebut. Sedangkan hasil video telah selesai pada semester ganjil 2020/2021.

Potensi keberlanjutan kegiatan PKM, melihat hasil kegiatan yang baik meskipun dilakukan secara daring memungkinkan pelaksana berkolaborasi lagi dengan guru-guru sekolah dasar untuk membuat materi lain untuk semester ganjil yang dirasa akan lebih baik jika ada penggambarannya secara animasi. Selain itu materimateri ini bisa digunakan juga untuk sekolah dasar lain yang mempunyai masalah yang sama selama melakukan pembelajaran jarak jauh.

Jika pembelajaran tatap muka sudah kembali dilakukan, hasil aset dari video animasi tersebut dapat disesuaikan menjadi media poster yang dapat ditempel di sisi-sisi kelas, sehingga siswa dapat melihat terus-menerus dalam keseharian mereka di sekolah, materi dalam poster tersebut akan tersimpan secara tidak langsung dalam alam bawah sadar mereka.

Selain itu materi-materi video animasi juga dapat dikomersilkan ke situs pembelajaran daring seperti ruangguru, zenius, quipper school, kelas pintar, ruang belajar, dan sebagainya. Situs-situs tersebut merupakan layanan pendidikan daring yang memfasilitasi guru dan murid dalam belajar dan mengajar daring. Dalam platform seperti ini guru bertugas sebagai fasilitator, artinya guru mempunyai tugas dalam pengelolaan materi sedangkan siswa dapat belajar dari rumah. Maka video-video animasi seperti luaran pada kegiatan PKM ini berpotensi untuk mendapat keuntungan jika dikomersilkan ke situs pembelajaran daring.

\section{KESIMPULAN}

Program PKM ini secara umum memiliki tujuan untuk membantu masyarakat khususnya pada bidang pendidikan selama pandemi covid-19 ini berlangsung. Penulis dimana memiliki latar belakang pendidikan seni dan desain mencoba memberikan solusi atas masalah yang timbul selama pembelajaran jarak jauh dilakukan dengan membuat edukasi visual dari materi ajar yang pada dasarnya sulit diajarkan saat tatap muka apalagi kini berubah menjadi daring.

Permasalahan yang timbul selama pembelajaran jarak jauh dilakukan antara lain: 1) Berkurangnya interaksi sosial antara guru dan murid. 2) Minimnya pengalaman belajar mengajar yang melalui proses improvisasi dan interaksi. Selain itu hal-hal teknis seperti tidak semua guru memiliki laptop, dan bisa mengoperasikan platform pembelajaran daring, serta siswa yang harus berbagi laptop dan handphone masih terjadi di SDN Jurang Mangu Timur 02 yang berada dalam kawasan urban. Dari permasalahan-permasalahan tersebut tim pelaksana berusaha memberikan solusi kreatif sesuai keilmuannya yaitu dengan membuat materi ajar berupa edukasi visual dalam bentuk video animasi.

Materi ajar menjadi tempat penting untuk bereksperimen, dengan edukasi visual yang berbasis video animasi sangat mungkin untuk ditambahkan aspek improvisasi ke dalam mediumnya. Adanya karakter guru dalam video animasi dapat menggantikan kehadiran guru secara fisik, guru tetap hadir secara simbolis dalam pemikiran dan konstruksi anak didik yang menyaksikan video tersebut. Dengan adanya kehadiran guru secara simbolis, murid dapat menempatkan diri sebagai narator maupun siswa yang belajar, sehingga murid juga dapat dilatih menjadi mandiri dengan peran 
ganda tersebut, sebagai pengajar/narator dan juga murid.

Dengan adanya video animasi pada materimateri yang sulit disampaikan secara daring, diharapkan dapat membantu penyampaian materi pada kegiatan belajar mengajar di SDN Jurang Mangu Timur 02. Serta dengan adanya penambahan proses interaksi dalam video animasi tersebut murid dan guru tetap dapat melakukan improvisasi dalam pembelajaran mereka, diharapkan murid dan guru mendapatkan pengalaman belajar-mengajar yang lebih baik, menarik, serta interaktif meskipun dilakukan secara jarak jauh.

\section{UCAPAN TERIMA KASIH}

Ucapan terima kasih disampaikan kepada Ibu Aminah selaku kepala sekolah SDN Jurang Mangu Timur 02 yang telah membantu kegiatan ini sehingga dapat berjalan dengan lancar. Serta guru-guru SDN Jurang Mangu Timur 02 dari kelas 1 hingga kelas 6; Ibu Erma, Ibu Tika, Ibu Yani, bapak Sudarmono, Ibu
Ayu, dan Ibu Noni, yang bersedia meluangkan waktunya dalam mendampingi mahasiswa pelaksana dalam proses pembuatan animasi materi ajar.

\section{REFERENSI}

Adu F.O. (2014). Improvisation as A Tool for Improving the Teachers Knowledge in Basic Technology. IOSR Journal of Research \& Method in Education, vol. 4, Issue 1, pp 14-18.

Buhl, M. (2011). So, what comes after? the current state of visual culture and visual education. Synnyt Origins: Finnish Studies in Art, (Issue 1).

Mayer, R. (2014). Multimedia Instruction. Handbook of Research on Educational Communications and Technology (pp. 385-399).

Mccloud, Scott. (1993). Understanding Comic: The Invisible Art. Harper Paperbacks.

Walter, E \& Gioglio, J. (2014). The Power of Visual Storytelling. McGraw-Hill Education. 